\title{
Vascular Basement Membrane Thickness in Muscle of Spiny Mice and Activities of Glycolysis and Gluconeogenesis in the Liver of Animals with Spontaneous and Experimental Diabetes and of Untreated Human Diabetics
}

\author{
W. Creutzfeldt, D. Mende, B. Willms and H. D. Söling \\ Department of Medicine, University of Goettingen, W.Germany
}

\begin{abstract}
Summary. Vascular basement membrane thickness in the muscle was measured in spiny mice according to the method of Siperstein et al. (1968). The mean basement membrane width in spiny mice with normal glucose tolerance was $73+16 \mathrm{~nm}$ and in spiny mice with moderately and severely impaired glucose tolerance $75 \pm 18$ and $80+18 \mathrm{~nm}$ respectively. In spiny mice with long lasting overt ketotic diabetes the basement membrane width was $105+9 \mathrm{~nm}$. This small increase is unlikely to be related to diabetes since it is within the range of basement membrane thiekness measured in normal swiss mice and far below the range described in human and experimental diabetes. - The activity of different enzymes of glycolysis and gluconoogenesis was measured in the liver of animals with experimental and spontaneous diabetes and in untreated human diabetes. The pattern of liver enzyme activity found under th 3 different conditions could be related to the type of diabetes present. In the case of insulin deficiency (acute streptozotocin diabetes of rats, ketotic type of diabetes of spiny mice and untreated human juvenile diabetes) there is a decrease in the activity of GK, PFK and PK while FDPase and G-6-Pase activity was increased and aldolase activity unchanged. In the case of non-ketotic diabetes (mild spontaneous diabetes of spiny mice, obese hyperglycemic Bar Harbor mics, New Zealand obese mice, human ma. turity onset type diabetes) the activity of glucokinase was significantly increased. While the activity of gluconeogenetic enzymes increased only in the more severe states of hyperglycemia, the activity of PK increased only in the milder forms of the non-ketotik diabetes.
\end{abstract}

Mesure de la membrane basale vasculaire du muscle de la souris à piquants activités enzymatiques de la glycolyse et et de la gluconéogénèse du foie dans le diabète spontané et expérimental de l'animal et le diabète humain

Résumé. L'épaisseur de la membrane basale vasculaire dans le muscle de la souris à piquantis a été déterminée selon la méthode de Siperstein et al. (1968). L'épaisseur moyenne de la membrane basale des souris à piquants ayant une tolórance normale au glucose est de $73 \pm 16 \mathrm{~nm}$ celle des animaux avec une tolérance au glucose modérément ou sévèrement déséquilibrée est respectivement de $75 \pm 18 \mathrm{~nm}$ et de $80 \pm 18 \mathrm{~nm}$. Chez la souris à piquants ayant un diabète cétosique franc de longue durée, l'épaisseur de la membrane basale est de $105 \pm 9 \mathrm{~nm}$. Cette petite augmontation peut difficilement être reliée au diabète parce qu'elle reste dans les limites des dimensions de la membrane basale observées chez les souris blanches normales et bien en dessous des valeurs trouvées dans le diabète humain et le diabète expérimental de l'animal. - L'activité de différentes enzymes de la glycolyse et de la gluconéogénèse a été mesurée dans le foie d'animaux ayant un diabète expérimental ou spontané ainsi que dans le diabète non-traité de l'homme. L'activité de différentes enzymes hépatiques sous différentes conditions est en relation avec le type du diabète.
Dans les cas d'une déficience en insuline (diabète aigu induit par la streptozotocine chez le rat, diabète cétosique de la souris à piquants et diabète juvénile non-traité chez l'homme), on observe une diminution de la glucokinase, de la phosphofructokinase et de la pyruvatekinase, alors que l'activité de la fructo-1,6-diphosphatase et la glucose-6-phosphatase sont accrues et l'activité de l'aldolase reste inchangée. Dans le diabète non-cétosique (diabète spontané léger de la souris à piquants, de la souris obèse-hyperglycémique de Bar Harbor, de la souris obèse de Nouvelle-Zélande et dans le diabète humain de type adulte), l'activité de la glucokinase est significativement accrue. Bien que l'activité des enzymes de la gluconéogénèse ne soit augmentée que dans les cas d'hyperglycémies les plus sévères, l'accroissement de l'activité de la pyruvatekinase n'est observé que dans les formes moins sévères de diabète non-cétosique.

Messungen der Basalmembran der Muskelkapillaren der Stachelmaus und glykolytische und gluconeogenetische Enzymaltivitäten der Leber bei experimentellem und Spontan-Diabetes von Tieren und beim menschlichen Diabetes

Zusammenfassung. Die Bestimmung des Durchmessers der Basalmembranen der Muskelcapillaren bei Stachelmäusen (Acomys cahirinus), nach der Methode von Siperstein et al. 1968 ergab bei Tieren mit normaler Glucosetoleranz $73+16 \mathrm{nM}$, bei Tieren mit leichter und schwerer Glucosetoleranzstörung $75 \pm 18$ resp. $80 \pm 18$ nM. Bei Tieren mit seit langem bestehendem ketotischen Diabetes betrug der $\varnothing 105 \pm 9$ nM. Dieser Wert liegt deutlich unter denjenigen, die bei Diabetikern und diabetischen Tieren gefunden wurden und entspricht ungefähr denjenigen, die bei normalen weißen Mäusen gemessen werden. Es ist deshalb nicht wahrscheinlich, daß die geringe bei Stachelmäusen beobachtete Zunahme auf die diabetische Stoffwechselstörung zurückgeführt werden kann. - In Leberhomogenaten von Tieren mit spontanem und experimentellem Diabetes sowie von unbehandelten Diabetikern wurde die Aktivität verschiedener Schlüsselenzyme der Glykolyse und der Gluconeogenese gemessen. Dies erlaubte es, den verschiedenen Schweregraden hyper. glykämischer Syndrome bestimmte Enzymmuster zuzuordnen. Im Falle oines Insulinmangels mit Keto-Acidose fand sich bei Mensch und Tieren ein Abfall der Aktivität von GK, PFK und PK. während die Aktivität von FD Pase und G-6-Pase anstieg und die Aldolase-Aktivität unverändert blieb. Nicht ketotische Hyperglykämie war durch eine Erhöhung der Aktivität der Glucokinase charakterisiert; die Aktivität der Schlüsselenzyme der Gluconeogenese war nur bei schwerer Hyperglykämie erhöht, während diejenige der Pyruvatkinase nur bei der leichten Form des nicht-ketotischen Diabetes erhöht war.

Key-words: spontaneous diabetes, diabetes in animals, diabetes in man, spiny mice, Acomys cahirinus, NZO mice, mutation $o b o b$, streptozotocin, liver enzymes, glycolysis, Gluconeogenesis, basement membrane, muscle, microangiopathy. 
I.

According to Siperstein et al. (1968) basement membrane thickness of muscle capillaries is increased in $98 \%$ of genetic human diabetics and in $53 \%$ of prediabetics, but seldom in diabetes due to chronic pancreatitis or in non-diabetic hyperglycemia. The authors concluded that vascular membrane thickness is not related to hyperglycemia per se but to the genetic diabetic syndrome of man. These findings are not unanimously accepted. Pometta et al. (1968) found no difference in the membrane thickness of muscle capillaries in normals, prediabetics and in diabetes of up to $2 \frac{1}{2}$ years duration. There are only few investigations in animals.

Siperstein et al. (1968) found no increase in membrane thickness of muscle capillaries in 2 chinese hamsters, 5 KK-mice and one sand rat with spontaneous diabetes. On the other hand, Bloodworth et al. (1969) recently described an increase in membrane thickness in dogs made diabetic by alloxan or somatotropic hormone. We measured the basement membrane thickness of muscle capillaries in normal and diabetic spiny mice (Acomys cahirinus) (Gonet et al. 1965, Hefti und Flïckiger 1967).

\section{Material and Methods}

The first spiny mice were given to us by Dr. E. Flückiger, Sandoz AG, Basel, Switzerland, and bred in our laboratory. Despite constant conditions and food and water ad libitum only one out of 64 animals
In the different groups there were animals of different age and weight, but the mean values were similar (Table 1). Group D are spiny mice with spontaneous severe diabetes with ketonuria from the laboratory of Dr. A. E. Renold, Institut de Biochimie clinique, Geneva. The data on these animals were given to us by Dr. W. Stauffacher.

Muscle tissue was taken from the m.gastrocnemius and fixed immediately in $2 \% \mathrm{Os}_{4}$ solution according to Dalton or in $3 \%$ glutaraldehyde and postfixed with $2 \% 0 \mathrm{s0}_{4}$ and after dehydration embedded in Mikropal. The different fixatives had no effect on the thickness of the basement membranes. In the case of the diabetic animals from Geneva, tissue from the m.psoas was fixed in $2 \% 0_{\mathrm{s}_{4}}$ solution according to Milloning and. embedded in Epon.

The material was cut with the LKB-microtome. Electron micrographs were made with the Zeiss EM 9 with a primary magnification of 10000 and the negatives magnified 3 times. Thus the membrane thickness was estimated on photographs of 30000 fold magnification. For each animal, 15 consecutive capillaries were measured according to the method of Siperstein et al. (1968).

\section{Results}

The basement membrane width of the muscle capillaries did not differ in the groups $\mathrm{A}, \mathrm{B}$ and $\mathrm{C}$ despite significant differences in carbohydrate tolerance in

Table 1. Grouping of the investigated spiny mice: Group $A-C$ according to the glucose tolerance (see text), Group $D$ - manifest diabetes. All data are mean values with standard deviation

\begin{tabular}{|c|c|c|c|c|c|c|}
\hline & \multirow{2}{*}{$\begin{array}{l}\text { Weight } \\
\text { (g) }\end{array}$} & \multirow{2}{*}{$\begin{array}{l}\text { Age } \\
\text { (days) }\end{array}$} & \multicolumn{3}{|c|}{ Glucose $\mathrm{mg} / 100 \mathrm{ml}$} & \multirow{2}{*}{$\begin{array}{l}\text { Basement } \\
\text { membrane } \\
\text { thickness } \\
(\mathrm{nm})\end{array}$} \\
\hline & & & $\overline{\text { fasting }}$ & peak & $120^{\prime}$ & \\
\hline \multirow{4}{*}{$\begin{array}{l}\text { Group A } \\
(\mathrm{n}=8) \\
\text { Group B } \\
(\mathrm{n}=6) \\
\text { Group C } \\
(\mathrm{n}=6) \\
\text { Group D } \\
(\mathrm{n}=5)\end{array}$} & $45 \pm 10$ & $220 \pm 146$ & $85 \pm 21$ & $131 \pm 16$ & $99 \pm 21$ & $73 \pm 16$ \\
\hline & $49 \pm 7$ & $254 \pm 190$ & $82 \pm 14$ & $244 \pm 29$ & $108 \pm 41$ & $75 \pm 18$ \\
\hline & $50 \pm 11$ & $207 \pm 125$ & $78 \pm 8$ & $\mathbf{3 7 4} \pm \mathbf{3 7}$ & $157 \pm 84$ & $80 \pm 18$ \\
\hline & & $462 \pm 174$ & $452 \pm 68$ & & & $105 \pm 9$ \\
\hline
\end{tabular}

developed a severe ketotic diabetes. Therefore, we performed glucose tolerance tests in 20 animals by injecting $0.2 \mathrm{~g}$ glucose ( $20 \%$ solution) per $100 \mathrm{~g}$ body weight intraperitoneally. Blood glucose was obtained by orbital bleeding and estimated enzymatically before and 30,60 and $120 \mathrm{~min}$ after the glucose injection. The animals were grouped according to the peak glucose levels after glucose loading:

Group A peak value below $200 \mathrm{mg} / 100 \mathrm{ml}$, group B peak value between 200 and $300 \mathrm{mg} / 100 \mathrm{ml}$, group C peak value above $300 \mathrm{mg} / 100 \mathrm{ml}$. these three groups (Table 1). This can be shown best by comparing the frequency distribution of basement membrane thickness (Fig. 1). The curves are identical in all three groups and show a skewed distribution to the right as described recently by Williamson et al. (1969).

Only the diabetic groups from Geneva exhibited slightly thicker basement membranes. This can be shown by comparing the frequency distribution of the combined groups A, B and C from our laboratory with the group D from Geneva (Fig. 2). The curve is 
slightly shifted to the right. Nearly identical is the distribution of basement membrane thickness of 5 swiss mice (age uniformly 270 days) which we investigated for comparison using the same technique as in the animals of group $\mathrm{A}-\mathrm{C}$. Their mean basement membrane width was $112 \pm 10 \mathrm{~nm}$.

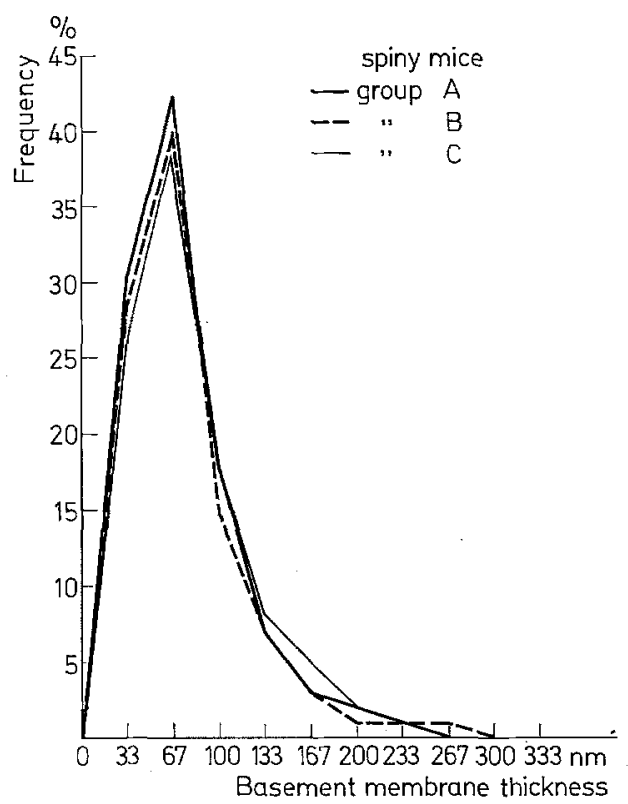

Fig. 1. Distribution in \% of vascular basement membrane thickness in muscle of three groups of spiny mice. (Grouping according to the GTT, see Table 1$)$

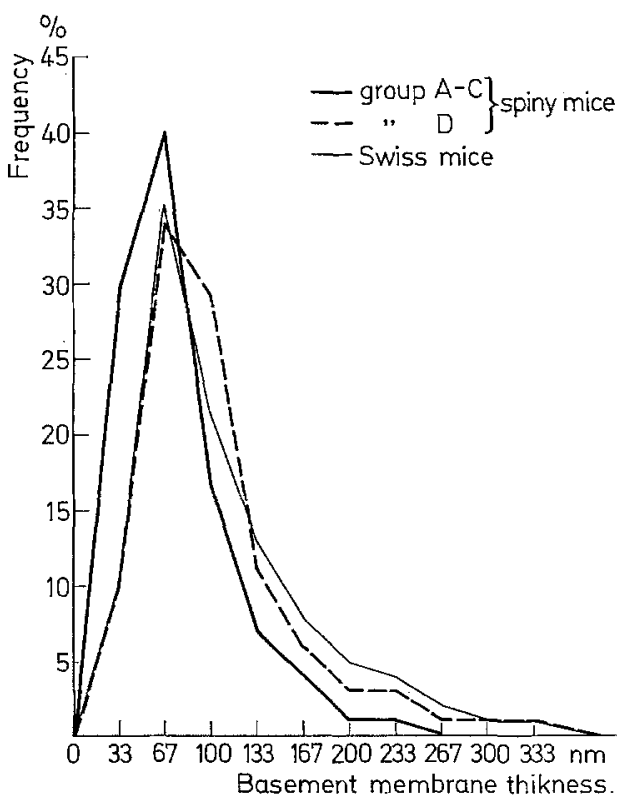

Fig. 2. Distribution in \% of vascular basement membrane thickness in muscle of spiny mice. The identical groups A, B and C (see Fig. 1) are summarized in one group and compared with group D (manifest diabetes, see Table 1) and a group of swiss mice
This slightly greater basement membrane width of the spiny mice with ketotic diabetes is by no means striking if one compares the differences found by Siperstein et al. (1968) between non-diabetic $(108 \mathrm{~nm})$ and diabetic $(240 \mathrm{~nm}$ ) human subjects or by Bloodworth et al. (1969) between non-diabetic $(76 \mathrm{~nm})$ and alloxan diabetic $(193 \mathrm{~nm})$ dogs. Also the duration of the diabetes was not very different regarding the different life expectancy of the two species: The alloxan diabetes of the dogs of Bloodworth et al. lasted between 278 and 1596 days, the manifest diabetes of the spiny mice of our group D lasted at least between 88 and 175 days.

By correlating the vascular basement membrane width to the age of the animals, an increase in width with increasing age could be seen (Fig. 3). No such correlation could be found between basement membrane width and body weight of the animals. Unfortunately the animals are not equally distributed over the whole age range. However, according to this obvious correlation the slightly greater basement membrane thickness found in the 5 spiny mice with manifest diabetes (squares in Fig. 3) could be explained by their greater age and can hardly be related to the diabetes.

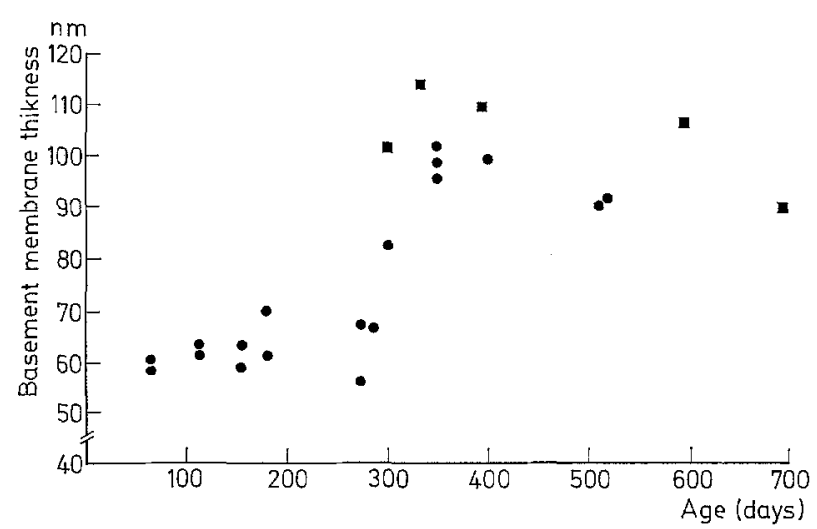

Fig. 3. Correlation between vascular basement membrane thickness and age of spiny mice with manifest diabetes (group $\mathrm{D}$ of Table $1=\mathbf{m}$ ) and of the animals of group $\mathrm{A}, \mathrm{B}$ and $\mathrm{C}$ of table $1(=0)$

In summary, we conclude from our investigations that in spiny mice the vascular basement membrane thickness of muscle does not increase significantly either in latent or in manifest diabetes of long duration.

\section{II.}

Now I will review shortly investigations done in our laboratory on liver enzyme activities in different forms of diabetes. These results were reported recently by Dr. Willms on the 5th Meeting of the European Association for the Study of Diabetes in Montpellier and will be published in detail elsewhere.

We investigated the activity of several enzymes of the carbohydrate metabolism in the liver of laboratory animals with experimental and spontaneous diabetes. 
These enzyme activities were compared with those from livers of untreated human diabetics. From measurements of certain insulin dependent enzyme activities we tried to get some information about enhanced or diminished effects of insulin on the liver - in other words, if there was an insulin resistance of the liver in types of diabetes with increased circulating levels of insulin in plasma.

The following enzymes were studied: The key gly. colytic enzymes glucokinase, hexokinase, phosphofructokinase and pyruvatekinase. Synthesis of glucokinase, but not hexokinase, is insulin dependent (Salas et al. 1963). Therefore this enzyme can be used as an indicator for the insulin effect on liver tissue. The gluconeogenic enzymes are increased during alloxan

Table 2. Characteristics of insulin deficiency diabetes of different species investigated

\begin{tabular}{|c|c|c|c|}
\hline & $\begin{array}{l}\text { Mean blood } \\
\text { glucose } \\
\mathrm{mg} / 100 \mathrm{ml}\end{array}$ & $\begin{array}{l}\text { Keton- } \\
\text { uria }\end{array}$ & $\begin{array}{l}\text { Age and } \\
\text { weight }\end{array}$ \\
\hline $\begin{array}{l}\text { I. Acute Strepto- } \\
\text { zotocin } \\
\text { diabetes of rats }\end{array}$ & 582 & + & \\
\hline $\begin{array}{l}\text { II. Ketotic type } \\
\text { diabetes } \\
\text { of spiny mice }\end{array}$ & 800 & $t$ & \\
\hline $\begin{array}{l}\text { III. Untreated human } \\
\text { juvenile } \\
\text { type diabetes }\end{array}$ & 375 & + & $\begin{array}{l}22-33 \\
\text { years } \\
-15 \% \\
\text { under- } \\
\text { weight }\end{array}$ \\
\hline
\end{tabular}

a Control of diabetes possible only with insulin.
Two enzymatic patterns could be observed in our experiments. The first one can be found in states of insulin deficiency, like streptozotocin diabetes, acute ketotic type of diabetes of the spiny mouse and untreated human juvenile type diabetes. The characteristics of this type of diabetes are given in Table 2.

The second enzymatic pattern can be found in states of diabetes without ketosis and with insulin or even hyperinsulinemia present as in mild spontaneous diabetes of spiny mice, obese hyperglycemic Bar Harbor mice, New Zealand obese mice and in untreated human maturity onset type diabetes. The characteristics of this second type of diabetes are given in Table 3.

The pattern of liver enzyme activities in diabetes due to insulin deficiency are given in Fig. 4. There is a decrease in the activity of glucokinase, phosphofructokinase and pyruvatekinase and an increase in activity of gluconeogenic enzymes like fructosediphosphatase and glucose-6-phosphatase while aldolase is unchanged.

Fig. 5 demonstrates the pattern of liver enzyme activities in the non-ketotic type of diabetes of different species. The striking difference to the insulin deficiency type of diabetes is a significant increase in activity of glucokinase. This corresponds well with the hyperinsulinemia known under these conditions and shows that the liver tissue is insulin sensitive and not insulin resistant in these types of diabetes. An increase in activity of gluconeogenic enzymes occurs only in the more severe states of the non-ketotic type of diabetes, i. e. if also the fasting blood glucose levels are elevated.

Table 3. Characteristics of non-ketotic type of diabetes in different species investigated

\begin{tabular}{|c|c|c|c|c|}
\hline & $\begin{array}{l}\text { Blood glucose } \\
\mathrm{mg} / 100 \mathrm{ml}\end{array}$ & GTT & $\begin{array}{l}\text { Keton- } \\
\text { uria }\end{array}$ & $\begin{array}{l}\text { Age and } \\
\text { weight }\end{array}$ \\
\hline $\begin{array}{l}\text { I. Mild diabetes } \\
\text { of spiny mice }\end{array}$ & $\begin{array}{l}93 \\
\text { (fasting) }\end{array}$ & pathol & $\emptyset$ & \\
\hline $\begin{array}{l}\text { II. Obese hyperglycemic } \\
\text { Bar Harbor mice }\end{array}$ & $\begin{array}{l}1.11 \\
\text { (fasting) }\end{array}$ & pathol. & $\phi$ & \\
\hline $\begin{array}{l}\text { III. New Zealand } \\
\text { obese mice }\end{array}$ & 154 & pathol. & $\phi$ & \\
\hline $\begin{array}{l}\text { IV. Untreated human } \\
\text { maturity onset type } \\
\text { diabetes }\end{array}$ & 339 & & $\begin{array}{l}5 \emptyset \\
2(+)\end{array}$ & $\begin{array}{l}47-61 \\
+31 \% \\
\text { overweight }\end{array}$ \\
\hline
\end{tabular}

¿ Control of diabetes possible with oral drugs.

diabetes, starvation and after injection of adrenocortical hormones (Weber et al. 1965). The activities of G-6-Pase and FDPase were determined as being representative for the gluconeogenic group. The activities of the bifunctional enzymes catalyzing both the glycolytic and gluconeogenic pathway are not significantly altered during alloxan diabetes or insulin administration. In the following study F-1,6-DP-aldolase was assayed as example of the bifunctional enzymes.
Probably the change in activity of the gluconeogenic enzymes is related to the stimulation of adrenocortical hormones and not to the lack of insulin. The aldolase activity is not significantly changed also in this type of diabetes.

Our results are in agreement with the findings of Weber et al. (1965) in alloxan diabetic rats, and of Seidman et al. (1967) and Coleman and Hummel (1967) in Bar Harbor mice. 
In summary, the comparison of the enzymatic activities in the liver tissue of different species with spontaneous or experimental diabetes enables us to correlate the type of diabetes in animals to the different types of diabetes in humans. It also shows that in the case of diabetes with hyperinsulinemia the liver tissue is insulin sensitive and not insulin resistant.

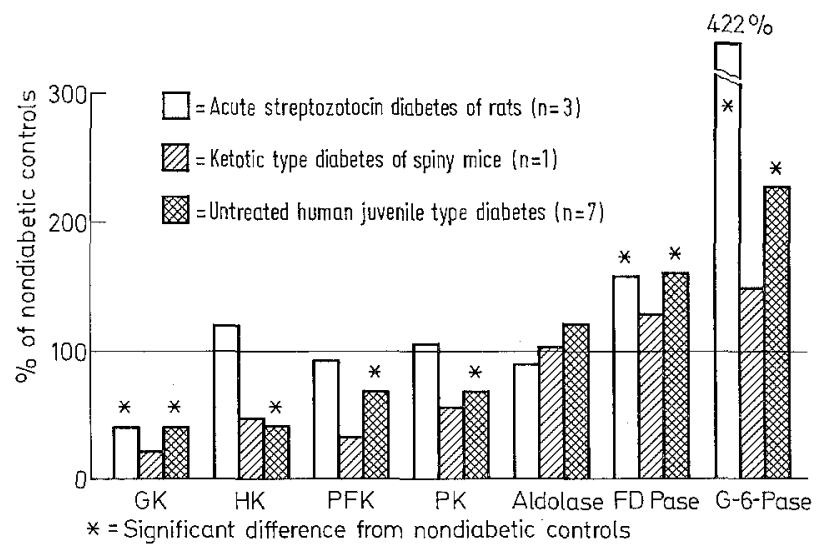

Fig. 4. Pattern of liver enzyme activities due to insulin deficiency in different species. (See Table 2)

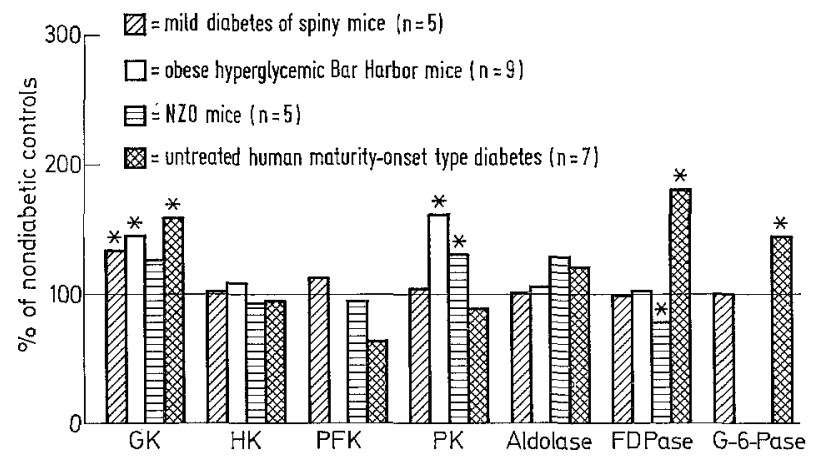

* = significant difference from nondiabetic controls

Fig. 5. Pattern of liver enzyme activities in non-ketotic type diabetes in different species. (See Table 3)
References

1. Bloodworth, J.M.B., Jr., Engerman, R.L., Powers, K.L.: Experimental diabetic microangiopathy. I. Basement membrane statistics in the dog. Diabetes 18 , $455-458$ (1969).

2. Coleman, D.L., Hummel, K.P.: Studies with the mutation, diabetes, in the mouse. Diabetologia 3, 238248 (1967).

3. Gonet, A.E., Stauffacher, W., Pictet, R., Renold, A. E.: Obesity and diabetes mellitus with striking congenital hyperplasia of the islets of Langerhans in spiny mice (Acomys cahirinus). Diabetologia 1, 162$171(1965)$.

4. Hefti, F., Flückiger, E.: Obesitas und Diabetes mellitus bei Acomys cahirinus. Rev. suisse Zool. 74, 562$566(1967)$.

5. Pometta, D., Orci, L., Rufener, C., Curchod, B.: Electron microscopic studies of the basement membrane of muscle capillaries of prediabetics, diabetics and non-diabetics. 4th Ann. Meet. of the Europ. Ass. for the Study of Diabetes, Louvain, July 22-24, 1968. Diabetologia 5, 52 (1969). Abstract.

6. Salas, H., Vinuela, E., Sols, A.: Insulin-dependent synthesis of liver glucokinase in the rat. J. biol. Chem. 238, 3535-3538 (1963).

7. Seidman, I., Horland, A.A., G.W. Teebor: Hepatic glycolytic and gluconeogenic enzymes of the obesehyperglycamic mouse. Biochim. biophys. Acta 146, $600-603(1967)$.

8. Siperstein, M.D., Unger, R.H., Madison, L.L.: Studies of muscle capillary basement membranes in normal subjects, diabetic, and prediabetic patients. J. clin. Invest. 47, 1973-1999 (1968).

9. Weber, G., Singhal, R.L., Srivastava, S.K.: Insulin: suppressor of biosynthesis of hepatic gluconeogenic enzymes. Proc. nat. Acad. Sci. 53, 96-104 (1965).

10. Williamson, J.R., Vogler, N.J., Kilo, C.: Estimation of vaseular basement membrane thickness. Theoretical and practical considerations. Diabetes 18, 567$578(1969)$.

11. Willms, B., Janson, A., Bernhard, G., Söling, H.D.: Hepatic enzyme activities of glycolysis and gluconeogenesis in hereditary diabetes of man and different laboratory animals. 5th Ann. Meet. of the Europ. Ass. for the Study of Diabetes, Montpellier, September $16-18,1969$.

Prof. Dr. W. Creutzfeldt

Department of Medicine

Medizinische Universitätsklinik

University of Göttingen

D-34 Göttingen, Humboldtallee 1 